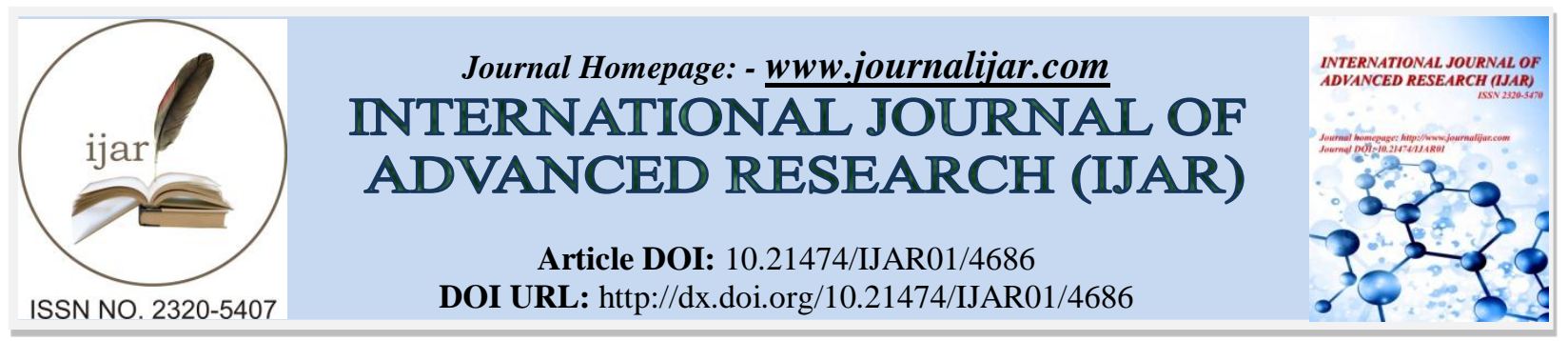

RESEARCH ARTICLE

\title{
THE DIMENSIONS OF BUYER BEHAVIOUR IN THE PURCHASE OF COSMETICS IN CHENNAI.
}

Research Scholar, Bharathiar University Coimbatore.

2. Professor - PSGR Krishnammal College for Women Coimbatore.

\section{Manuscript Info}

(.........................

Manuscript History

Received: 1 May 2017

Final Accepted: 3 June 2017

Published: July 2017

Key words:-

Buyer Behavior, cosmetics, Buying

Motives, Buying Habits.

\section{Abstract}

Grasping Buyer Behavior is what a Marketer has to do. No wonder, the study of buyer behavior has become very vital now. So there is need to identify the dimensions of the buyer and decode the consumer behavior. This study attempts to provide a view towards buyer behaviour. A sample of 82 female cosmetic users was selected. The results confirm with what has been largely theoretical ideas of linkages between the buyer characteristics and the importance that they place on different criteria during the decision-making process. The results are supported with the analysis that has been made with the data gathered during the study.

Copy Right, IJAR, 2017,. All rights reserved.

\section{Introduction:-}

The old adage says 'Give a lady what she wants' serves as an evergreen statement on the smart marketing. Marketing is certainly understanding 'the lady', and creating a customer out of her through understanding. The question is how does one understand what a lady would want and what buying behavior she would have. The cosmetics brand has to deliver the relevant value to the buyer. The value is what the consumer considers or presumes as the value, and the cosmetic seller has to go by her choice and deliver her the value she seeks. To accomplish this target the cosmetics brand, need to understand its consumers fully about their preference and behavior.

Consumer does not go by set rules in her buying Decision:-

When a buyer takes a buying decision, no rigid rule binds her. Sometimes she takes the decision on the spot. In some cases she decides after a long search, after evaluating the various alternatives available, after reassuring herself with the opinion of those who have already purchased the product. Sometimes, the buyer goes to a shop after taking decision to buy a product, but does not buy it! For apparent reason, she postpones the purchase or even drops the idea or may switch the decision to purchase some other product!

Consumers are characterized by greater amount of complexity. Due to the environment they operate and the knowledge and awareness they possess. They also cope with the information overload, they enjoy with multitude of choices. The choices often confuse them. The sales environment is also complex with large number of competitors in the cosmetics segment. 
Buying Motives And Buying Habits:-

Sangeeta Sahney, Koustab Ghosh, Archana Shrivastava (2013), from the perspective of the seller, it is the attempt on the seller's part to attract and persuade the prospect to conduct the purchase decision-making process, and ensure satisfaction and loyalty. From the perspective of the buyer,online purchase behavior is the degree to which consumer access, browse, shop and transact and repeat the behavior with the revolution in the very basics of transaction from a physical store format to a non-store one. It is important to understand the factors that could motivate Indian consumers to indulge in online buying.

Nizar Souiden, Mariam Diagne (2009), clarify the impact of personal variables(self-image consciousness, ageing effects,physical attractiveness, state of health), socio-cultural variables(ie. Beliefs, life style) and marketing variables (ie. Advertising, purchase situation). Consumers motivations and attitudes differ among markets when the product is at different stages of the lifecycle.

Tracy Scelzo, Dawn Lerman (2009), the unique pressures of growing up as a little emperor in achanging society are widely reflected in product usage and the ways in which ease the tension and anxiety associated with the pressure of maintaining expectations from friends, family and society.

Gerard Cliquet, Jean-Philippe Croizen (2002), exploratory study of several cosmetics retail companies operating in the French market seem to indicate that developing services is the best way of retailing business independence and resisting predators.

Sharmila Pudaruth, Thanika Devi Juwaheer, Yogini Devi Seewoo (2015), identified that the purchasing patterns for eco-friendly cosmetics and beauty care products is influenced by a combination of eight factors namely: "Women lifestyles, self-image health and economic considerations", "ethical consumerism among females", "Pharamacological essence of green cosmetics and beauty care products", "visual appeal and physical cues in cosmetics stores", "Price-conscious decisions and effective promotion", "belief on ethical claims in green messages, "brand image and usage experience" and "sales representatives and social influences". The behavioral intension and referral of female customers is primarily derived from factors related to "Women lifestyles, self image, health and economic conditions".

Vesselina Dimitrova, Mariana Kaneva, Teodoro Gallucci (2009) indicate that the role of the customers in the cognitive process of knowledge accumulation for the specific and rare aromatic rose products is captive, based on a new learning for the nature of the product and application of integrated marketing ideas for the product development and promotion.

J.Michael Weber, Julie Capitant De Villebonne (2002), suggests that a difference should exist due to psychological factors, social influences, and the purchase situation.

Amanda Coley, Brigitte Burgers, (2003), affective process components (irresistible urge to buy, postivebuying emotion and mood management) and cognitive process components (cognitive deliberation and unplanned buying) significant differences were also found between men and women in the frequency with which the product categories were purchased on impulse.

Eun Joo park, Eun Young Kim, Judith Cardona Forney (2006), Fashion involvement and positive emotion had positives effects on consumers fashion-oriented impulse buying behavior with fashion involvement having the greatest effect. Hedonic consumption tendency was an important mediator in determining fashion-oriented impulse buying.

George P. Moschis, Leah Bovell (2013) shows the differences in the way older consumers respond to various marketing offerings. They vary widely by psychographic characteristics that are based on aging, life changing events and circumstances older consumers have experienced.

\section{Review Of Literature:-}

Liz barnes, Gaynor lea, Greenwood, Margaret Bruce Lucy Daly (2006), states the buying practices for fast fashion, namely, a combination of global and local suppliers. Trust is an important factor in the supplier-retailer 
relationship to ensure fast delivery at an agreed quality and integration of key internal activities and processes to facilitate the speed of buying decisions that may be required.

Dominic F.Wilson, (2000), states the buyer behavior literature between the contexts of consumer markets and organisational markets has lead to a split approach to the development of buyer behavior theory.

John F.Tanner, Jr.(1990), states the need for industrial marketers to undertake buyer behavioral choices, which are affected by various factors, concludes that the development of a successful marketing strategy requires the accurate prediction of buyer bahvior.

John Ramsay, BeverlyWagner, Stephen Ketty (2013), defines to improve performance through an enhanced ability of organisations as buyer to influence supplier behavior by modifying aspects of their own behavior. It should be particular interest to all organisations with buyers with vey low levels of power trying to improve the responsiveness of more powerful suppliers.

Susan Sproule, Norm Archer (2000), states about the buyer behavior framework. A fruitful application area for software agents is in the area of e-commerce, where potential buyers can easily be overwhelmed by the flood of information that is available, thus potentially making less than optimal purchasing decisions.

R.R.Dholakia (1979), suggests that the buying behavior decision is influenced by extra-personal pervasion and the intra-personal influence of a buyer's personal behavior. Suggests that the creative design of marketing is dependent on an understanding of these two processes, which, it revealed could lead to a remarkably different response.

Sam Swallow, (1971) states, it is often assumed that the behavior patterns of the domestic consumer and the industrial buyer are fundamentally different. The industrial buyer is not buying for himself but for his organization. He therefore makes his decisions in relation to his organisation's objectives and behaves as a logical animal. He buys to tight specifications and is equipped to judge the reasonableness of prices.

Antonis Simintires Adamantios, Diamantopoules Judith Ferriday (1997), explains about the pre-purchase satisfaction on the first -time buyers and its likely impact on buying behavior. Indicates that pre-purchase satisfaction can be distinguished from anticipated satisfaction and that it helps to predict first-time purchases.

George A Luffman (1974), explains the aspects of the communication process, which relate to the conditions determining the alertness of the individual buyer to marketing communicative and the manner in which he/she searches the market. Identifies the extent of market search by buyers.

Rui da Silva, Gary Davis, Pete Naude (2002), states the influence of certain retail buyer characteristics, how the buyers approach and their buying task.

\section{Objectives Of The Study:-}

- To know the buying motives of the cosmetic users.

- To know the buying habits of the cosmetic users.

\section{Hypothesis Of The Study:-}

H1: Buying motives influences buyer responses.

H2: Buying Habits influences the buyer responses.

\section{Research Methodology:-}

\section{Target Population:-}

The study targeted the 82 (Women Cosmetic Users) Respondents in Chennai. The population of study consisted of women Cosmetic users in Chennai. Cosmetic products and their users on a daily basis, what are their buying motives and habits to choose their products? A survey study was adopted.

\section{Data Collection:-}

The data was collected using questionnaires. A set of selected questions was used to collect data from the respondents in the sample population. These include close-ended questions. Each item of the questionnaire was 
developed to address a specific objective of the study.

\section{Response:-}

The total of 82 questionnaires administered during the study, Demographic Characteristics, the profile of the respondents is looked upon in terms of Age, Level of education, Marital Status, Average Monthly Income and Frequency of Shopping, the researcher sought to establish these characteristics from the respondents.

\section{Data Analysis:-}

The statistical tool has used to analyze the data collected for the study. The SPSS was used. Chi-square, Anova was applied to the study.

\section{Chi-Square:-}

\begin{tabular}{|c|c|c|c|c|c|c|}
\hline \multirow{2}{*}{} & \multicolumn{3}{|c|}{ Cases } & \multicolumn{2}{c|}{ Total } \\
\cline { 2 - 6 } & \multicolumn{2}{|c|}{ Valid } & \multicolumn{2}{|c|}{ Missing } & \multicolumn{2}{c|}{ Percent } \\
\cline { 2 - 6 } & $\mathrm{N}$ & Percent & $\mathrm{N}$ & Percent & $\mathrm{N}$ & $100.0 \%$ \\
\hline Age * Monthly spending & 85 & $100.0 \%$ & 0 & $0.0 \%$ & 85 & $100.0 \%$ \\
\hline $\begin{array}{c}\text { Age * why do you use } \\
\text { cosmetics }\end{array}$ & 82 & $96.5 \%$ & 3 & $3.5 \%$ & 85 & \\
\hline Age * Where do you buy & 82 & $96.5 \%$ & 3 & $3.5 \%$ & 85 & $100.0 \%$ \\
\hline
\end{tabular}

\begin{tabular}{|l|l|l|l|}
\hline & Value & df & Asymp. Sig. (2-sided) \\
\hline Pearson Chi-Square & $221.392^{\mathrm{a}}$ & 30 & .000 \\
\hline Likelihood Ratio & 156.366 & 30 & .000 \\
\hline N of Valid Cases & 85 & & \\
\hline
\end{tabular}

Chart showing Respondents monthly spending towards cosmetics

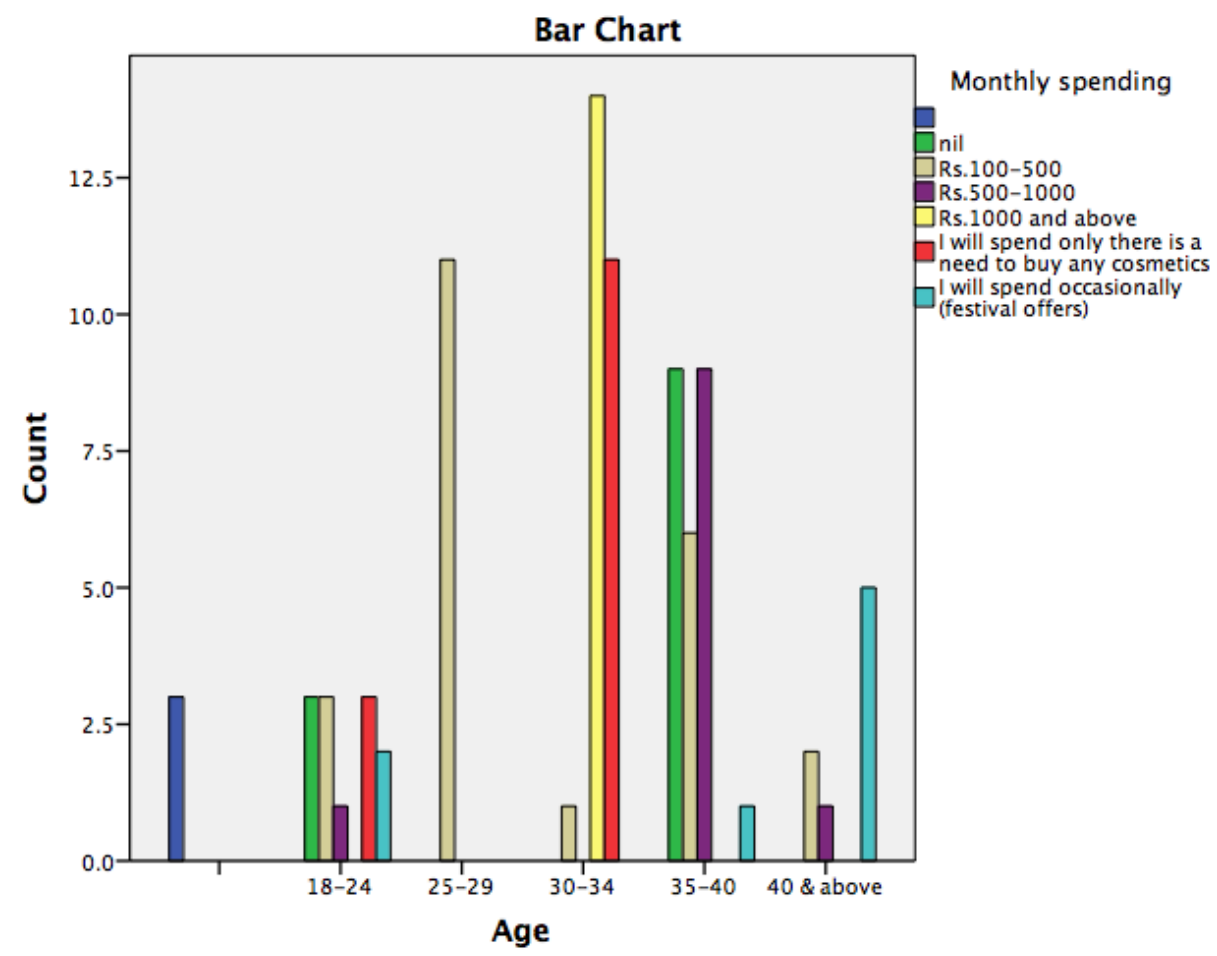


Income* Monthly spending

\begin{tabular}{|c|c|c|c|}
\hline \multicolumn{4}{|c|}{ Chi-Square Tests Table No:3 } \\
\hline & Value & df & Asymp. Sig. (2-sided) \\
\hline Pearson Chi-Square & $122.724^{\mathrm{a}}$ & 30 & .000 \\
\hline Likelihood Ratio & 71.836 & 30 & .000 \\
\hline N of Valid Cases & 85 & & \\
\hline
\end{tabular}

Chart showing Respondents Monthly spending towards cosmetics

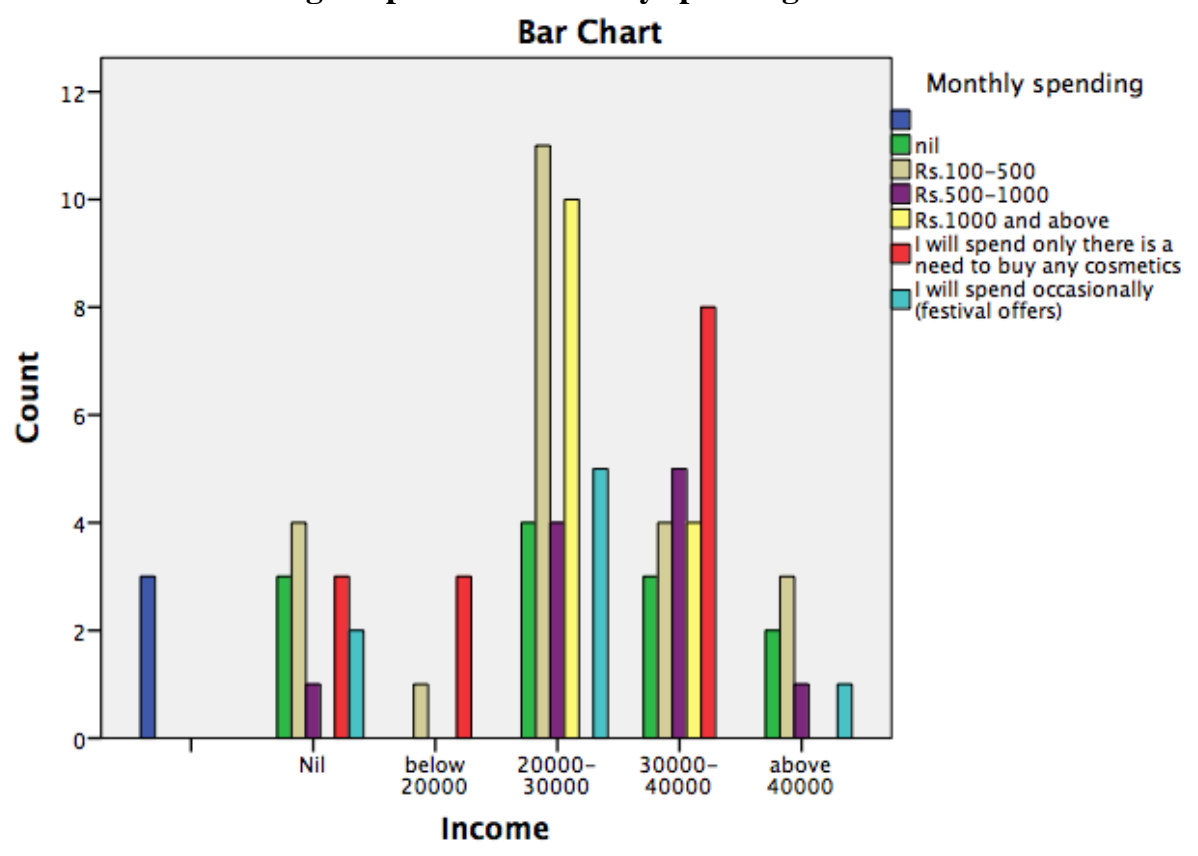

Age*why do you use cosmetics

\begin{tabular}{|c|c|c|c|}
\hline \multicolumn{3}{|c|}{ Chi-Square Tests Table No:4 } & Asymp. Sig. (2-sided) \\
\hline & Value & 12 & .000 \\
\hline Pearson Chi-Square & $44.572^{\mathrm{a}}$ & 12 & .000 \\
\hline Likelihood Ratio & 50.184 & & \\
\hline
\end{tabular}




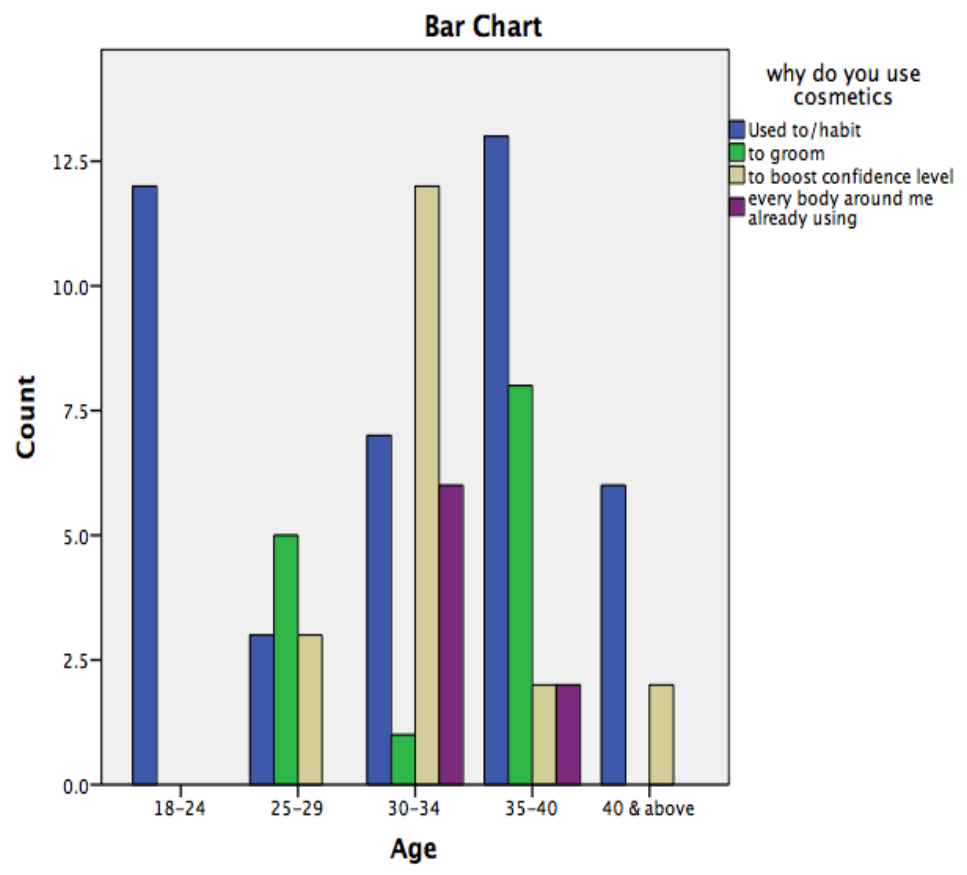

Age*where do you buy Cosmetics

\begin{tabular}{|c|c|c|c|}
\hline \multicolumn{3}{|c|}{ Chi-Square Tests Table No:5 } & Asymp. Sig. (2-sided) \\
\hline & Value & 12 & .336 \\
\hline Pearson Chi-Square & $13.468^{\text {a }}$ & 12 & .154 \\
\hline Likelihood Ratio & 16.873 & & \\
\hline N of Valid Cases & 82 & & \\
\hline
\end{tabular}


Chart showing where do the respondents buy their cosmetics.

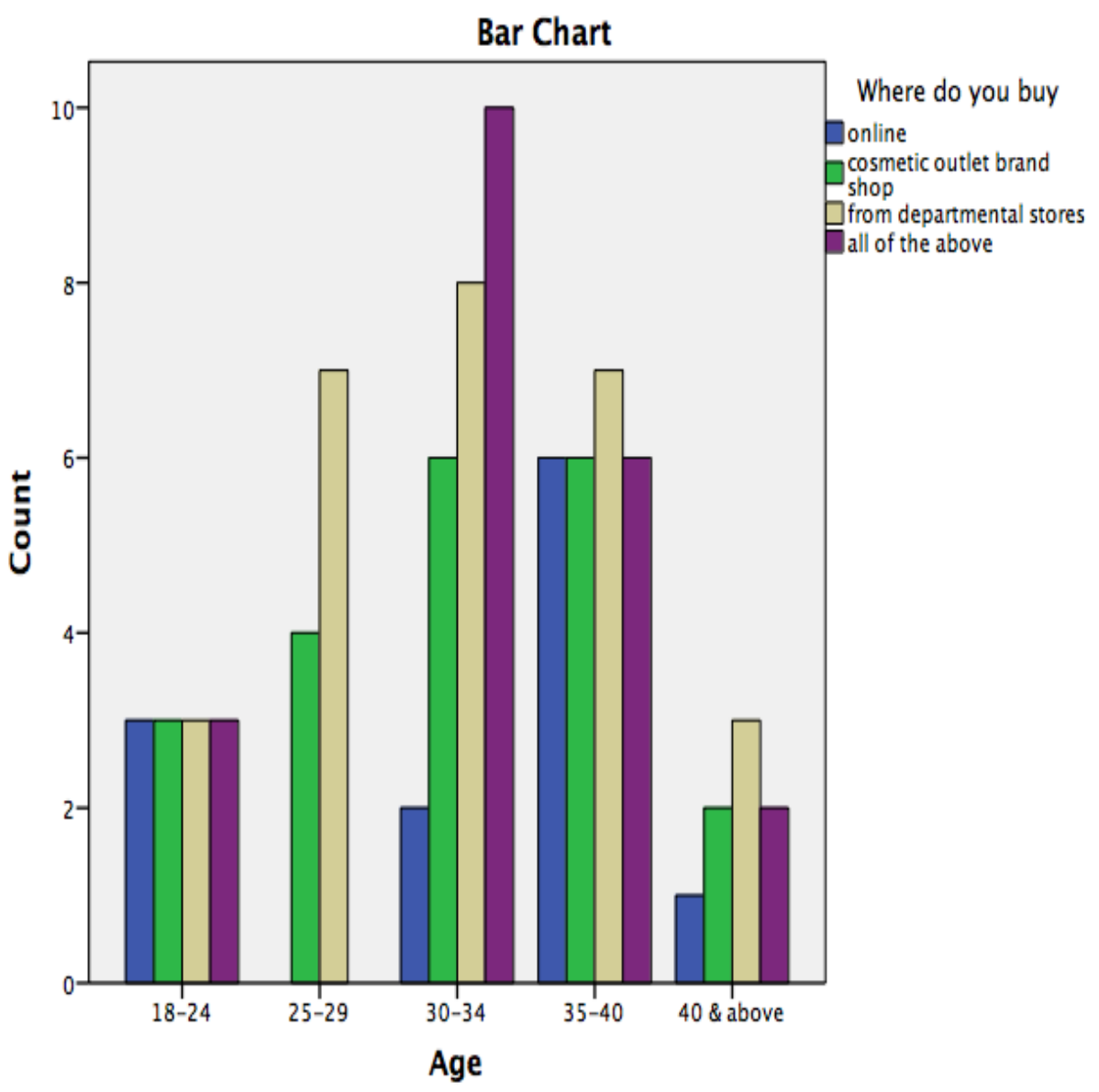

Anova:-

Anova is tested for the Brand Impression and the factors that influence the band impression

\begin{tabular}{|c|c|c|c|c|c|}
\hline \multicolumn{6}{|c|}{ Anova Table showing Brand Impression and its variables } \\
\hline \multirow{4}{*}{$\begin{array}{c}\text { Brand Impression } \\
\text { This is one of the best brand } \\
\text { cosmetics products, I could have } \\
\text { bought }\end{array}$} & $\begin{array}{l}\text { Sum of } \\
\text { Squares }\end{array}$ & c & \multicolumn{2}{|c|}{ Mean Square } & $\mathrm{F}$ \\
\hline & 7.625 & 5 & 1.525 & 2.495 & .069 \\
\hline & 11.000 & 18 & .611 & & \\
\hline & 18.625 & 23 & & & \\
\hline \multirow{3}{*}{$\begin{array}{l}\text { This brand hasn't worked out } \\
\text { well as, I expected }\end{array}$} & 1.650 & 5 & .330 & 1.760 & .302 \\
\hline & .750 & 4 & .188 & & \\
\hline & 2.400 & 9 & & & \\
\hline \multirow[t]{3}{*}{ This brand is exactly what I need } & 1.917 & 5 & .383 & 2.208 & .121 \\
\hline & 2.083 & 12 & .174 & & \\
\hline & 4.000 & 17 & & & \\
\hline \multirow[t]{3}{*}{ I am satisfied with my decision } & 7.828 & 5 & 1.566 & 2.180 & .125 \\
\hline & 8.617 & 12 & .718 & & \\
\hline & 16.444 & 17 & & & \\
\hline \multirow{3}{*}{$\begin{array}{l}\text { In general I have strong interest } \\
\text { in this brand }\end{array}$} & 9.000 & 2 & 4.500 & 9.000 & .022 \\
\hline & 2.500 & 5 & .500 & & \\
\hline & 11.500 & 7 & & & \\
\hline
\end{tabular}




\section{Findings and Discussions:-}

Buying Motives \& Habits:-

- From the analysis, it is identified that the main buying motive of the cosmetics is that all age category of the respondents state that they are used to or it's a habit of using the cosmetics

- Majority of them also state that to boost the confidence level is also the reason they use the cosmetics.

- In the age group of 35-40 agree that buying motive of cosmetics is to groom themselves.

- From the analysis, it is identified that majority of them buy the cosmetics from the departmental stores. The next option that all age group mentioned was that they use all the sources like (online, cosmetics outlet brand shop) for buying the cosmetics.

- Its been identified that age group of 30-34 spend more on the cosmetics monthly.

- Respondents, who's monthly income was more than Rs.20000, spent more on cosmetics

- The brand impression and its related factors state that the respondents are satisfied with the decision they made on the cosmetics brand, they felt that this could be one of the best brands they have bought. They also agree that, the cosmetic brand that they bought for them worked well, as expected. They have strong interest on the brand that they have chosen for them.

\section{Conclusion:-}

All purchase situations are not uniform. And, the level of consumer involvement in the purchase varies, in line with the buying situation. There are high-involvement as well as low involvement buying situations. The situations vary essentially on account of the difference in the products and what it takes on the part of the consumer to arrive at the buying decision. The situations in which the consumers are placed also impact their shopping behavior. There is always a tradeoff between time to be spent and price to be paid, in the transaction. The values of time and money vary from consumer to consumer. This has enhanced the need for them to shop their cosmetics in the departmental store and online stores as well. Their characteristics differ and needs differ and their shopping behavior is accordingly distinct in cosmetics buying behavior.

\section{Reference:-}

1. Aaker, Jennifer L. (1997), "Dimensions of Brand Personality," Journal of Marketing Research, 34 (August), 347-356.

2. Alpert, F. \& Kamins, M. (1994) "Pioneer Brand Advantage and Consumer Behavior: A Conceptual Framework and Propositional Inventory," Journal of the Academy of Marketing Science, 22 (3): 244-254.

3. Amanda Coley, Brigitte Burgess, "Gender differences in cognitive and affective impulse buying", Journal of Fashion Marketing and Management: An International Journal, Volume: 7 Issue: 3, 2003

4. Anna Saraneva, Maria Sääksjärvi, "Young compulsive buyers and the emotional roller-coaster in shopping",Young Consumers", Volume: 9 Issue: 2, 2008

5. Bhat, S. \& Reddy, S. (1998) "Symbolic and Functional Positioning of Brands," Journal of Consumer Marketing, 15 (1): 32-44.

6. Baldinger, A. \& Rubinson, J. (1996) "Brand Loyalty: The Link Between Attitude and Behavior, "Journal of Advertising Research, 36 (6): 22-35.

7. Bernhard, M. (2001) "Criteria for Optimal Web Design," available at http://www.optimalweb.org

8. Biel, Alexander (1993), "Converting Image Into Equity," in Brand Equity and Advertising,

9. Bruner, R., Harden, L., Heyman, B., \& Amato, M. (2000) NetResults.2, Best Practices for Web Marketing. Indianapolis, IN. New Riders Publishing, p.283.

10. Castro, Maria C. F. (1995), Iberia in Prehistory. Oxford: Blackwell Publishers Ltd.

11. Chaudhuri, A. \& Holbrook, M. (2001) "The Chain Effects from Brand Trust and Brand Affect to Brand Performance: The Role of Brand Loyalty," Journal of Marketing, 65 (2): 81-94.

12. Clifford, Richard (1990), "Phoenician Religion," Bulletin of the American Schools of Oriental Research, 279 (August), 55-66.

13. Corstjens, M. \& Lal, R. (2000) "Building Store Loyalty through Store Brands," Journal of Marketing Research, 37 (3): 281-292.

14. Cowles, D. (1997) "The Role of Trust in Customer Relationships: Asking the Right Questions," Management Decision, 35 (3/4): 273-283. 
15. Deitel, H., Deitel, P., \& Steinbuhler, K. (2001) e-Business and e-Commerce. Upper Saddle River, NJ: Prentice-Hall.

16. Eun Joo Park, Eun Young Kim, Judith Cardona Forney, "A structural model of fashion-oriented impulse buying behavior", Journal of Fashion Marketing and Management: An International Journal", Volume: 10 Issue: 4, 2006

17. Gérard Cliquet, Jean-Philippe Croizean, "Towards plural forms, franchising/company-owned systems, in the French cosmetics retail industry", International Journal of Retail \& Distribution Management, Volume: 30 Issue: 5, 2002

18. George P. Moschis, Leah Bovell, "Marketing pharmaceutical and cosmetic products to the mature market ", International Journal of Pharmaceutical and Healthcare Marketing, Volume: 7 Issue: 4, 2013

19. J. Michael Weber, Julie Capitant de Villebonne, "Differences in purchase behavior between France and the USA: the cosmetic industry", Journal of Fashion Marketing and Management: An International Journal, Volume: 6 Issue: 4, 2002

20. Nizar Souiden, Mariam Diagne, "Canadian and French men's consumption of cosmetics: a comparison of their attitudes and motivations", Journal of Consumer Marketing, Volume: 26 Issue: 2, 2009

21. Perry Patsy, Kyriakaki Margarita, "The decision-making process of luxury fashion retail buyers in Greece", Journal of Fashion Marketing and Management: An International Journal", Volume: 18 Issue: 1, 2014

22. Sharmila Pudaruth, Thanika Devi Juwaheer, Yogini Devi Seewoo, "Gender-based differences in understanding the purchasing patterns of eco-friendly cosmetics and beauty care products in Mauritius: a study of female customers", Social Responsibility Journal, Volume: 11 Issue: 1, 2015

23. Taehyun Kim, Hoon-Young Lee, "External validity of market segmentation methods: A study of buyers of prestige cosmetic brands", European Journal of Marketing, Volume: 45 Issue: 1/2, 2011

24. Tricia Johnson, Julianne Attmann, "Compulsive buying in a product specific context: clothing", Journal of Fashion Marketing and Management: An International Journal, Volume: 13 Issue: 3, 2009

25. Vesselina Dimitrova, Mariana Kaneva, Teodoro Gallucci, "Customer knowledge management in the natural cosmetics industry”, Industrial Management \& Data Systems, Volume: 109 Issue: 9, 2009 